\title{
Phycoremediation of fish farm wastewater by Chlorella sorokiniana and autochthonous microalgae
}

Ficorremediação da água residual da piscicultura por Chlorella sorokiniana e microalgas autóctones Ficorremediación de aguas residuales de piscifactorías por Chlorella sorokiniana y microalgas autóctonas

Emerson Machado de Carvalho ORCID: https://orcid.org/0000-0002-4865-6784 Universidade Federal do Sul da Bahia, Brazil E-mail: carvalho.em@gmail.com

Carolina Ramos dos Santos ORCID: https://orcid.org/0000-0003-0677-7745 Federal University of Grande Dourados, Brazil E-mail: crsbiotec@hotmail.com

Mônica Ansilago

ORCID: https://orcid.org/0000-0002-7866-3619 Federal University of Grande Dourados, Brazil E-mail: monica_ansilago@hotmail.com

Mariana Lara Menegazzo

ORCID: https://orcid.org/0000-0001-8029-0279 Federal University of Grande Dourados, Brazil

E-mail: marianamenegazzo@ufgd.edu.br

Nathaskia Silva Pereira Nunes

ORCID: https://orcid.org/0000-0002-0433-6412 Federal University of Grande Dourados, Brazil E-mail: nathaskia.spn@gmail.com

\begin{abstract}
With the disorderly increase in global environmental problems, the cultivation of aquatic organisms is a promising path for sustainable food production. The quality of water, both at the entrance and exit of the production of aquatic animals, needs to be maintained following the parameters specified by local legislation. This study aimed to investigate the removal of contaminants from fish farming wastewater associated with the production of freshwater microalgae biomass. Six completely randomized treatments were used in triplicate: with the addition of microalgae $C$. sorokiniana in fish farm wastewater $(\mathrm{W}+\mathrm{Cs})$, the addition of $C$. sorokiniana in wastewater enriched with NPK fertilizing $(\mathrm{W}+\mathrm{F}+\mathrm{Cs})$ or sugarcane vinasse $(\mathrm{W}+\mathrm{V}+\mathrm{Cs})$, only wastewater $(\mathrm{W})$, wastewater supplemented with fertilizer $(\mathrm{W}+\mathrm{F})$ or vinasse $(\mathrm{W}+\mathrm{V})$. The wastewater was used in natura to allow the development of autochthonous microalgae. The microalgae $C$. sorokiniana grew rapidly in effluents enriched with NPK and vinasse. After 28 days of bioassay, the concentrations of several contaminants in the water were reduced: zinc (20 to 88\%), lead (5 to 83\%), aluminum (56 to $75 \%$ ), manganese (56 to $72 \%$ ), cadmium (9 to 52\%), calcium (16 to 24\%) and magnesium (12 to 33\%). Our results indicated that the production of microalgae biomass can be integrated with the treatment of fish farming effluents to reduce the environmental burden and increase the economic bonus for adopting a sustainable production method. However, our results also indicated the importance of introducing a microalgae strain with high productive performance and supplementing the wastewater to obtain rapid biomass.
\end{abstract}

Keywords: Aquaculture; Bioassay; Environmental biotechnology; Chlorophyceae; Kinetics.

\section{Resumo}

Com a escalada dos problemas ambientais globais, o cultivo de organismos aquáticos é um caminho promissor para a produção sustentável de alimentos. A qualidade da água, tanto na entrada como na saída da produção de animais aquáticos precisa ser mantida de acordo com os parâmetros especificados pela legislação local. Este estudo teve como objetivo investigar a remoção de contaminantes da água residual da piscicultura consorciado à produção de biomassa de microalgas dulcícolas. Foram utilizados seis tratamentos inteiramente casualizados em triplicata: com adição da microalga $C$. sorokiniana em água residual da piscicultura $(\mathrm{W}+C s)$, adição de $C$. sorokiniana em água residual enriquecida com fertilizando NPK $(\mathrm{W}+\mathrm{F}+C s)$ ou vinhaça de cana-de-açúcar $(\mathrm{W}+\mathrm{V}+C s)$, somente água residual $(\mathrm{W})$, água residual suplementada com fertilizante $(\mathrm{W}+\mathrm{F})$ ou vinhaça $(\mathrm{W}+\mathrm{V})$. A água residual foi utilizada in natura para permitir o desenvolvimento de microalgas autóctones. A microalga $C$. sorokiniana cresceu rapidamente em efluentes enriquecidos com NPK e vinhaça. Após 28 dias de bioensaio as concentrações de vários contaminantes na água foram 
reduzidas: zinco (20 a 88\%), chumbo ( 5 a 83\%), alumínio (56 a 75\%), manganês (56 a 72\%), cádmio (9 a $52 \%$ ), cálcio (16 a 24\%) e magnésio (12 a 33\%). Nossos resultados indicaram que a produção de biomassa microalgácea pode ser integrada ao tratamento de efluentes da piscicultura de forma a diminuir o ônus ambiental e aumentar o bônus econômico por adotar um método de produção sustentável. Porém, nossos resultados também indicaram a importância de introduzir uma cepa de microalga com alto desempenho produtivo e suplementar a água residual para obter biomassa rápida.

Palavras-chave: Aquicultura; Bioensaio; Biotecnologia ambiental; Chlorophyceae; Cinética.

\begin{abstract}
Resumen
Con el aumento desordenado de los problemas ambientales globales, el cultivo de organismos acuáticos es un camino prometedor para la producción sostenible de alimentos. La calidad del agua, tanto a la entrada como a la salida de la producción de animales acuáticos, debe mantenerse de acuerdo con los parámetros especificados por la legislación local. Este estudio tuvo como objetivo investigar la eliminación de contaminantes de las aguas residuales de la piscicultura asociados con la producción de biomasa de microalgas de agua dulce. Se utilizaron seis tratamientos completamente aleatorizados por triplicado: con adición de microalgas $C$. sorokiniana en aguas residuales de piscifactoría (W+ Cs), adición de $C$. sorokiniana en aguas residuales enriquecidas con fertilizante NPK $(\mathrm{W}+\mathrm{F}+\mathrm{Cs})$ o vinaza de caña de azúcar -de- azúcar $(\mathrm{W}+\mathrm{V}+\mathrm{Cs})$, solo aguas residuales $(\mathrm{W})$, aguas residuales suplementadas con fertilizante $(\mathrm{W}+\mathrm{F})$ o vinaza $(\mathrm{W}+\mathrm{V})$. El agua residual se utilizó in natura para permitir el desarrollo de microalgas autóctonas. La microalga $C$. sorokiniana creció rápidamente en efluentes enriquecidos con NPK y vinaza. Después de 28 días de bioensayo, las concentraciones de varios contaminantes en el agua se redujeron: zinc (20-88\%), plomo (5-83\%), aluminio (56-75\%), manganeso (56-72\%), cadmio (9-52\%), calcio (16-24\%) y magnesio (12-33\%). Nuestros resultados indicaron que la producción de biomasa de microalgas se puede integrar con el tratamiento de los efluentes de la piscicultura para reducir la carga ambiental y aumentar la bonificación económica por adoptar un método de producción sostenible. Sin embargo, nuestros resultados también indicaron la importancia de introducir una cepa de microalgas con alto rendimiento productivo y complementar las aguas residuales para obtener biomasa rápida.
\end{abstract}

Palabras clave: Acuicultura, Bioensayo, Biotecnología ambiental, Chlorophyceae, Cinética.

\title{
1. Introduction
}

Fish farming is economically important and has been growing at a notably higher rate than other rural industries. According to the SOFIA report (The State of World Fisheries and Aquaculture) of the FAO (Food and Agriculture Organization of the United Nations), fish accounts for $20 \%$ of the total animal protein consumed worldwide (triennial report 2013-2015), and in 2016 global fish production was 171 million tonnes (FAO, 2018).

With the escalation of global environmental issues, the farming of aquatic organisms is a promising avenue for sustainable food production. However, fish farming, like any other activity in the productive sector, needs to be sustainable, which requires complete overall knowledge of associated processes and adopting practices to remedy and/or minimize the potential negative impacts of production on the environment (Ballester-Moltó, Sanchez-Jerez, Cerezo-Valverde \& AguadoGiménez, 2017).

Water quality is vital for fish health and that can be influenced by a variety of factors, including $\mathrm{pH}$, dissolved oxygen, organic matter, mineral content, and presence of pathogens (Banerjee \& Ray, 2017). Therefore, the quality of water used in the production of aquatic animals needs to be maintained according to parameters specified by the local legislation. It is also necessary that the quality of the effluent generated by productive systems is high to minimize harmfully affecting receiving water bodies.

Several tools are needed to ensure proper food quality and safety in the production of aquaculture products, and for this purpose, the FAO has developed numerous documents which outline how to achieve these objectives, such as the Code of Conduct for Responsible Fisheries and the Technical Guidelines for Aquaculture Certification. The Environmental Protection Agency of The United States (USEPA, 1986) has provided guidelines concerning water quality that details the permitted concentrations of harmful compounds in aquatic environments intending to protect aquatic life after both short and long-term exposure.

Low-cost alternative measures can be incorporated into the productive processes of aquacultures to mitigate the negative effects of fish farming effluent discharge. Among these technologies, microalgae are particularly promising as they require a 
large number of nutrients and are resilient to metals and other contaminants found in effluents (Jung et al., 2017). These microorganisms allow the independent maintenance of water in their respective fish tanks, decreasing the volume of effluent needing to be released into water bodies.

Microalgae are unicellular organisms, often exhibiting little or no cellular differentiation and being capable of converting solar energy into chemical energy via $\mathrm{CO}_{2}$ fixation more efficiently than higher plants (Sathasivam, Radhakrishnan, Hashem \& AbdAllahd, 2019). They are predominantly aquatic and microscopic and are considered a very heterogeneous group of microorganisms. They have the potential to produce various biomolecules such as lipids, carbohydrates, and proteins and are used in the pharmaceutical and food industries (Mostafa, 2012).

Algae are also of significant use in the performance of bioassays, in the mitigation of environmental damage, and wastewater treatment systems such as biofloc technologies (Jung et al., 2017). Microalgae are capable of assimilating inorganic compounds, heavy metals, and nutrients present in aquatic environments (Mcginn et al., 2012; Wuang, Khin, Chua \& Luo, 2016) and have been increasingly employed in laboratory cultivation tests due to their high productivity and the ease at which they are maintained (Carvalho et al., 2012; Ansilago, Otonelli \& Carvalho, 2016).

Among the microalgae that are commonly used in industry, the genus Chlorella includes green microalgae which are used as supplements in human food and animal feed (Sathasivam et al., 2019). The species Chlorella sorokiniana is small-sized algae $(4.5 \mu \mathrm{m})$ that grow rapidly, exhibits high biomass production, has a competitive advantage over other species, and can be grown in mixotrophic environments. Therefore it is ideal for cultivation in wastewater (Lizzul et al., 2014).

The use of algal biomass requires its separation from the liquid medium in which it is contained. One of the most common techniques used to recover algal biomass is centrifugation, which, while highly efficient and relatively fast, often causes cell damage through cell disruption and has high energy- and equipment-related costs, and requires considerable maintenance (Barros, Gonçalves, Simões \& Pires, 2015). Flocculation with different organic and inorganic agents is also frequently used, being a low-cost method with high efficiency and the capacity to process large volumes of liquid media.

Singh, Singh and Taggar, (2017) compared the separation of biomass by centrifugation and the use of chitosan as a flocculant and found that the two methods were $98.4 \%$ and $97.23 \%$ efficient, respectively. Kim et al. (2017) assessed the use of ferric sulfate in the recovery of Chlorella sp. biomass via chemical flocculation and reported efficiencies of up to $98 \%$ using a concentration of $0.9 \mathrm{~g} \mathrm{~L}^{-1}$. Lal and Das (2016) tested the efficiency of ferric chloride and alum (potassium aluminum sulfate) in the flocculation of Chlorella sp. and also reported efficiencies of up to $98 \%$ using $1 \mathrm{~g} \mathrm{~L}^{-1}$ chemical compounds.

Given the above, the objective of this study was to evaluate the removal of residual water contaminants in fish farms using freshwater microalgae in a controlled environment bioassay. To define the experimental design, we raised two hypotheses: 1. Supplementation of fish farming wastewater with vinasse or NPK chemical fertilizer could induce the development of autochthonous microalgae and, therefore, allow phycoremediation of pollutants in the environment; 2 . The introduction of the microalgae Chlorella sorokiniana strain in fish farm wastewater supplemented with vinasse or NPK chemical fertilizer may increase the efficiency of the phytoremediation of pollutants in the environment.

\section{Methodology}

\subsection{Bioassays}

Chlorella sorokiniana (Trebouxiophyceae) - André Tosello Foundation reference number 211-32) - was used in bioassays. Wastewater was collected from fish farms in tarpaulin tanks at properties in the municipality of Glória de Dourados, MS. The bioassay design was completely randomized, containing six treatments in triplicate, totaling 18 experimental units: treatments with the addition of microalgae $C$. sorokiniana only in wastewater $(\mathrm{W}+C s)$, the addition of microalgae $C$. sorokiniana in fish farm wastewater supplemented with NPK chemical fertilizer $(\mathrm{W}+\mathrm{F}+C s)$ or vinasse $(\mathrm{W}+\mathrm{V}+C s)$, only autochthonous 
microalgae grown in fish farm wastewater (W), only autochthonous microalgae grown in fish farm wastewater supplemented with NPK chemical fertilizer $(\mathrm{W}+\mathrm{F})$ or vinasse $(\mathrm{W}+\mathrm{V})$.

To supplement the wastewater $10 \mathrm{~mL}$ per liter of NPK stock solution or $1 \mathrm{~mL}$ per liter of crude sugarcane vinasse were added. Wastewater was not autoclaved to preserve autochthonous microorganisms. The stock solution NPK was prepared with $0.70 \mathrm{~g} \mathrm{~L}^{-1}$ of N:P:K chemical fertilizer (20-5-20 $\mathrm{g} \mathrm{L}^{-1}$ ) according to the methods of Carvalho et al. (2012). The composition of the crude vinasse was: Zinc $(\mathrm{Zn})$ 1.60, Lead (Pb) 0.4, Cadmium (Cd) 0.05, Nickel (Ni) 0.20, Iron (Fe) 42.50, Manganese (Mn) 5.50, Copper $(\mathrm{Cu})$ 0.95, Chrome (Cr) 0.07, Cobalt (Co) 0.22, Aluminum (Al) 43.80, Calcium (Ca) 1.13, Magnesium (Mg) 234, Sodium (Na) 25.30, Potassium (K) 2.45, Boron (B) 27.3, Nitrogen (N) 0.06, Phosphorus (P) $0.06\left(\mathrm{mg} \mathrm{L}^{-1}\right)$.

The bioassays were packaged in suspended plastic bags $(1000 \mathrm{~mL})$ for 28 days using a non-axenic static culture system, constant aeration, a controlled room temperature, and a photoperiod of 2500 lux provided by white fluorescent lamps (12 h light / $12 \mathrm{~h}$ dark). Samples were collected from 18 experimental units every 7 days apart to measure the cell duplication rates and monitor the $\mathrm{pH}$ and electrical conductivity of the water. Microalgae were identified and grouped into Chlorella sp. and others. For the Chlorella sp. it was not possible to distinguish between the species of the pure strain introduced in the treatments (Chlorella sorokiniana) and the native species. The duplication rate was calculated by counting cells in a Neubauer chamber and calculated by dividing the difference between the algal density values from the last and first day of the experiment by the time elapsed in days.

After 28 days of bioassay, the 18 experimental units were flocculated with $0.75 \mathrm{~g}$ of ferric chloride $\left(\mathrm{FeCl}_{3}\right)$ per liter and filtered on qualitative filter paper (Whatman ${ }^{\circledR}$ Grade 40 Circles) to separate the microalgal biomass. The samples were acidified with $1 \%$ nitric acid and conditioned in a refrigerator for analysis of their physical and chemical composition.

The chemical analysis of samples was performed at the Laboratory of Applied Mass Spectrometry and Chromatography (LECA - Laboratório de Espectrometria e Cromatografia Aplicada) of the Faculty of Exact Sciences and Technology (FACET Faculdade de Ciências Exatas e Tecnologia) of UFGD. The analyses were performed using flame atomic absorption spectrometry (FAAS). The chemical elements measured in the analysis were: Copper $(\mathrm{Cu})$, Iron (Fe), Manganese (Mn), Zinc (Zn), Calcium (Ca), Magnesium (Mg), Chromium (Cr), Lead (Pb), Molybdenum (Mo), Aluminium (Al), Cadmium (Cd), and Nickel (Ni). The procedures for the collection, storage, and analysis of the samples followed the methods detailed in the Standard Methods for Examination of Water and Wastewater (APHA, 2005).

\subsection{Data Analysis}

To verify statistical differences in the data of cell duplication rate, $\mathrm{pH}$, and electrical conductivity of the culture medium, an analysis of variance was used to compare the six treatments (ANOVA $p<0.05$ ), followed by the Tukey test. Tests were also carried out to verify significant differences in the percentage of contaminants removed for each treatment. The original data were transformed to suit the analysis used.

To evaluate the nutrient reduction potential as analyzed using FAAS, the concentrations of each nutrient present in whole samples were subtracted from those of the supernatant both before and after chemical flocculation. The amount of each nutrient removed throughout the experiment was expressed as a percentage and calculated using the following equation (1).

$\mathrm{R} \%=\left(\frac{\left(\mathrm{C}_{0}-\mathrm{C}_{\mathrm{e}}\right.}{\mathrm{C}_{0}}\right) \times 100$

\section{Equation (1)}


Where $\mathrm{C}_{0}$ and $\mathrm{C}_{\mathrm{e}}$ are the concentrations of the nutrient in the liquid phase $\left(\mathrm{mg} \mathrm{L}^{-1}\right)$ before and after chemical flocculation, respectively.

\section{Results}

The cell duplication rate of microalgae of the group composed of Chlorella species was significantly higher in treatments with fish farm wastewater supplemented with chemical fertilizer NPK and sugarcane vinasse $\left(\mathrm{F}_{5,16}=343,12 \mathrm{p}<0.001\right)$. Treatment with $C$. sorokiniana cultivated only in fish farm wastewater (without supplementation) or treatments with only highaltitude microalgae showed a low duplication rate (Figure 1). These values demonstrate that the microalgae C. sorokiniana supplemented with fertilizer or vinasse had the highest product performance.

The hydrogenic potential of the culture medium measured on the 28th day showed a trend towards more acidic values for the treatments supplemented with the chemical fertilizer NPK (Figure 2a). The electrical conductivity of water also showed $a$ trend for treatments supplemented with fertilizer with higher values (Figure $2 b$ ).

The results of the percentage reduction in a load of pollutants after the period of microalgae cultivation were: (1) a reduction in the contaminants aluminum, cadmium, magnesium, lead and zinc was observed in all treatments; (2) the contaminants calcium and manganese showed reduction in some treatments; (3) the contaminants chromium, copper, nickel, cobalt, and molybdenum were below the limit of detection (LD); (4) the iron contaminant increased the concentration by about 99\% (Table 1). Despite these results, a pattern of increase in the removal rate was not observed as a function of supplementation of the culture medium or the addition of the $C$. sorokiniana strain to the culture medium.

Figure 1. Duplication rates of microalgae in each treatment as measured on the $28^{\text {th }}$ day of the experiment (mean \pm standard error): treatments with the addition of $C$. sorokiniana only in wastewater $(\mathrm{W}+C s)$, the addition of $C$. sorokiniana in wastewater supplemented with fertilizer $(\mathrm{W}+\mathrm{F}+C s)$ or vinasse $(\mathrm{W}+\mathrm{V}+C s)$, only autochthonous microalgae grown in wastewater $(\mathrm{W})$, autochthonous microalgae grown in wastewater supplemented with fertilizer $(\mathrm{W}+\mathrm{F})$ or vinasse $(\mathrm{W}+\mathrm{V})$. Analysis of variance was performed $(p<0.05)$ followed by the Tukey test when comparing the rows, where equal letters indicate statistically equal means and different letters indicate statistically different means.

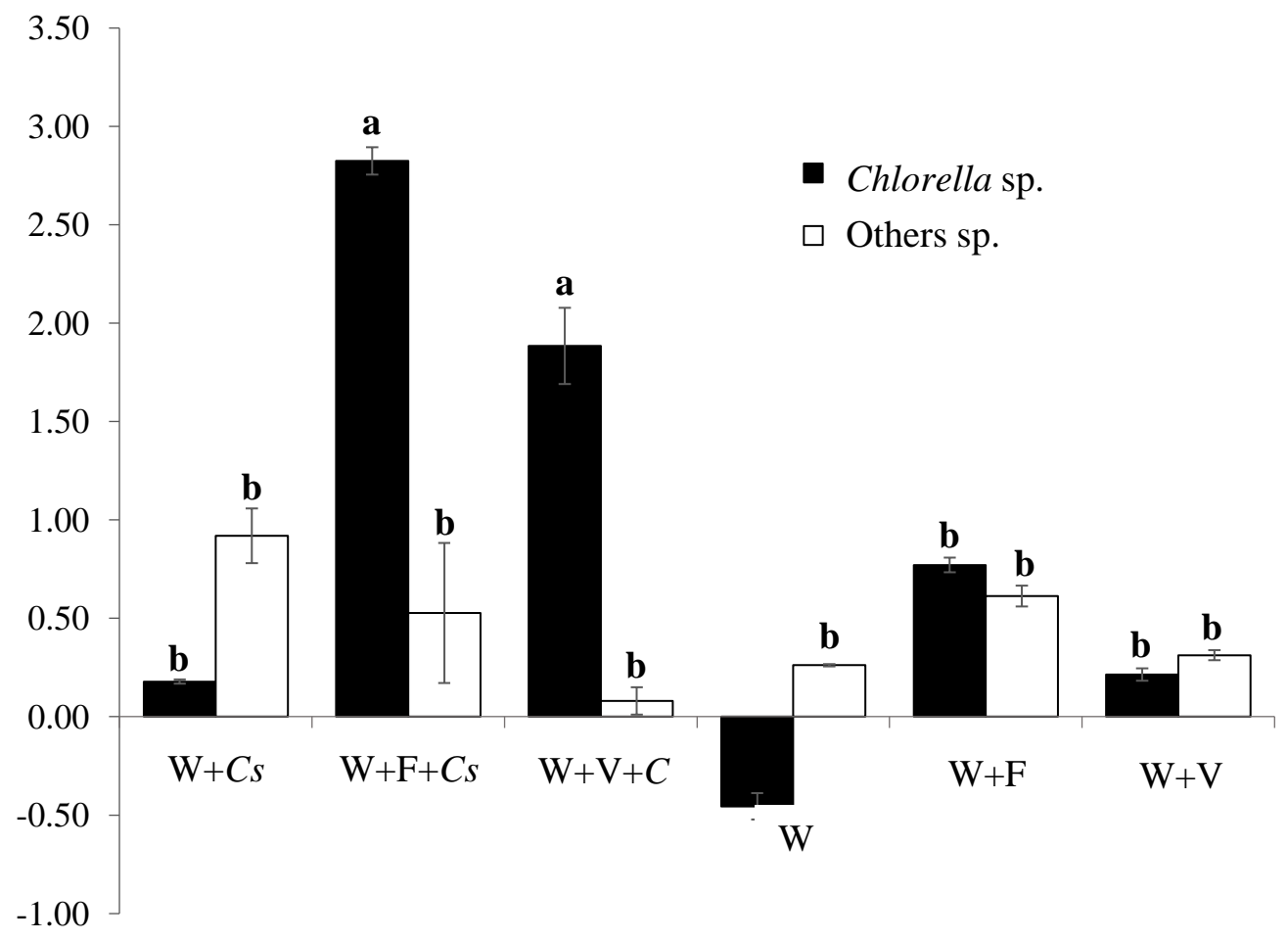

Source: Authors. 
Figure 2. pH monitoring (a) and conductivity (b) of treatments (mean \pm standard error) on the $28^{\text {th }}$ day of culture: subtitles see Figure 1.
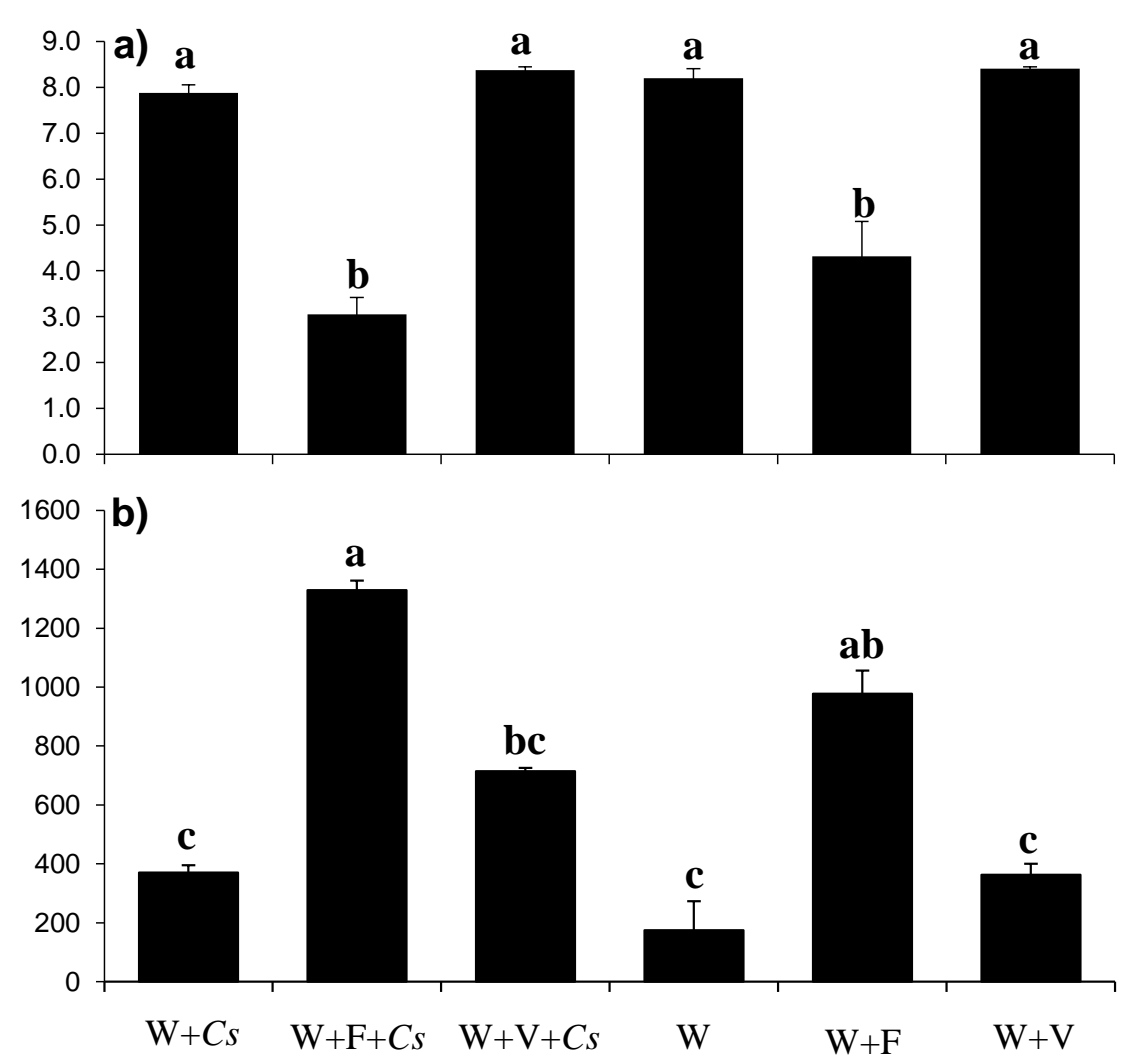

Source: Authors. 
Table 1. Rate of reduction in the concentration of pollutants present in the culture medium after 28 days of bioassay (mean \pm standard error): subtitles see Figure 1 .

\begin{tabular}{|c|c|c|c|c|c|c|c|c|}
\hline & $\mathrm{W}+C s$ & $\mathrm{~W}+\mathrm{F}+C s$ & $\mathrm{~W}+\mathrm{V}+C s$ & $\mathbf{W}$ & $\mathbf{W}+\mathbf{F}$ & $\mathbf{W}+\mathbf{V}$ & $\mathbf{F}$ & $P$ \\
\hline $\mathbf{F e}$ & $\begin{array}{c}-99.24^{\mathrm{NS}} \\
\pm 0.01\end{array}$ & $\begin{array}{c}-99.98^{\mathrm{NS}} \\
\pm 0.06\end{array}$ & $\begin{array}{c}-99.52^{\mathrm{NS}} \\
\pm 0.01\end{array}$ & $\begin{array}{c}-99.79^{\mathrm{NS}} \\
\pm 0.02\end{array}$ & $\begin{array}{c}-99.87^{\mathrm{NS}} \\
\pm 0.01\end{array}$ & $\begin{array}{c}-99.61 \mathrm{NS} \\
\pm 0.04\end{array}$ & 748.30 & 0.64 \\
\hline Al & $\begin{array}{l}55.54^{\text {в }} \\
\pm 0.65\end{array}$ & $\begin{array}{c}60.37^{\text {В }} \\
\pm 0.54\end{array}$ & $\begin{array}{c}58.97^{\text {в }} \\
\pm 5.31\end{array}$ & $\begin{array}{c}62.06^{\mathrm{AB}} \\
\pm 1.74\end{array}$ & $\begin{array}{c}51.59^{\mathrm{B}} \\
\pm 1\end{array}$ & $\begin{array}{c}74.94^{\mathrm{A}} \\
\pm 0\end{array}$ & 11.54 & $<0.05$ \\
\hline Cd & $\begin{array}{c}50.82^{\mathrm{A}} \\
\pm 6.93\end{array}$ & $\begin{array}{c}45.85^{\mathrm{AB}} \\
\pm 0.86\end{array}$ & $\begin{array}{l}8.91 \text { В } \\
\pm 1.78\end{array}$ & $\begin{array}{l}52.07^{\mathrm{A}} \\
\pm 2.71\end{array}$ & $\begin{array}{c}20.17 \mathrm{AB} \\
\pm 9.77\end{array}$ & $\begin{array}{l}12.06^{\mathrm{AB}} \\
\pm 12.38\end{array}$ & 7.86 & $<0.05$ \\
\hline Mn & $<\mathrm{LD}$ & $\begin{array}{c}72.48 \mathrm{NS} \\
\pm 7.24\end{array}$ & $\begin{array}{c}55.13^{\mathrm{NS}} \\
\pm 7.99\end{array}$ & $<\mathrm{LD}$ & $<\mathrm{LD}$ & $<\mathrm{LD}$ & 9.36 & 0.06 \\
\hline Mo & $<\mathrm{LD}$ & $<\mathrm{LD}$ & $<\mathrm{LD}$ & $<\mathrm{LD}$ & $<\mathrm{LD}$ & $<\mathrm{LD}$ & - & - \\
\hline Mg & $\begin{array}{c}21.71^{\mathrm{BC}} \\
\pm 0.49\end{array}$ & $\begin{array}{l}23.81^{\text {B }} \\
\pm 0.68\end{array}$ & $\begin{array}{l}12.19^{\mathrm{D}} \\
\pm 2.66\end{array}$ & $\begin{array}{c}16.92^{\mathrm{CD}} \\
\pm 0.11\end{array}$ & $\begin{array}{c}19.86^{\mathrm{BC}} \\
\pm 0.19\end{array}$ & $\begin{array}{l}33.13^{\mathrm{A}} \\
\pm 0,13\end{array}$ & 38.50 & $<0.05$ \\
\hline $\mathbf{P b}$ & $\begin{array}{l}82.61^{\mathrm{A}} \\
\pm 0.03\end{array}$ & $\begin{array}{c}34.93^{\mathrm{B}} \\
\pm 1.47\end{array}$ & $\begin{array}{l}75.84^{\mathrm{A}} \\
\pm 2.62\end{array}$ & $\begin{array}{l}71.62^{\mathrm{A}} \\
\pm 1.21\end{array}$ & $\begin{array}{l}5.50^{\mathrm{C}} \\
\pm 4.58\end{array}$ & $\begin{array}{l}44.55^{\mathrm{B}} \\
\pm 1.54\end{array}$ & 156.11 & $<0.05$ \\
\hline Zn & $\begin{array}{c}84.06^{\mathrm{AB}} \\
\pm 0.28\end{array}$ & $\begin{array}{c}65.65^{\mathrm{C}} \\
\pm 0.3\end{array}$ & $\begin{array}{c}79.81^{\mathrm{B}} \\
\pm 2.82 \\
\end{array}$ & $\begin{array}{c}88.36^{\mathrm{A}} \\
\pm 0.33\end{array}$ & $\begin{array}{c}66.50^{\mathrm{C}} \\
\pm 0.35 \\
\end{array}$ & $\begin{array}{c}19.67 \mathrm{D} \\
\pm 1.27\end{array}$ & 378.64 & $<0.05$ \\
\hline $\mathrm{Cr}$ & $<\mathrm{LD}$ & $<\mathrm{LD}$ & $<\mathrm{LD}$ & $<\mathrm{LD}$ & $<\mathrm{LD}$ & $<\mathrm{LD}$ & - & - \\
\hline $\mathrm{Cu}$ & $<\mathrm{LD}$ & $<\mathrm{LD}$ & $<\mathrm{LD}$ & $<\mathrm{LD}$ & $<\mathrm{LD}$ & $<\mathrm{LD}$ & - & - \\
\hline $\mathbf{N i}$ & $<\mathrm{LD}$ & $<\mathrm{LD}$ & $<\mathrm{LD}$ & $<\mathrm{LD}$ & $<\mathrm{LD}$ & $<\mathrm{LD}$ & - & - \\
\hline $\mathrm{Ca}$ & $\begin{array}{c}24.05^{\mathrm{NS}} \\
\pm 1.89\end{array}$ & $\begin{array}{c}16.29^{\mathrm{NS}} \\
\pm 2.32\end{array}$ & $<\mathrm{LD}$ & $\begin{array}{c}20.44^{\mathrm{NS}} \\
\pm 0.11\end{array}$ & $\begin{array}{c}14.33^{\mathrm{NS}} \\
\pm 0.61\end{array}$ & $\begin{array}{c}11.04^{\mathrm{NS}} \\
\pm 3.83\end{array}$ & 1.42 & 0.33 \\
\hline Co & $<\mathrm{LD}$ & $<\mathrm{LD}$ & $<\mathrm{LD}$ & $<\mathrm{LD}$ & $<\mathrm{LD}$ & $<\mathrm{LD}$ & - & - \\
\hline
\end{tabular}

Source: Authors.

Analysis of variance was performed $(p<0.05)$ followed by the Tukey test when comparing the rows, where equal letters indicate statistically equal means and different letters indicate statistically different means. ${ }^{\text {NS }}$ is not significant. < LD: below the limit of detection. Subtitles see Figure 1.

\section{Discussion}

In the present work we used alternative means - NPK chemical fertilizer and sugarcane vinasse - to supplement fish farm wastewater and produce biomass of the microalgae $C$. sorokiniana in a controlled laboratory bioassay. When cultivated in effluent enriched with either fertilizer or vinasse, the duplication rate of the microalgae Chlorella sorokiniana was significantly increased. We also adopted the same supplementation procedure to stimulate the production of autochthonous microalgae biomass from fish farm wastewater. We inferred the great potential of bioremediation of contaminants in the culture medium in association with the production of microalgae biomass. The results of this study indicated that supplementation with alternative media was essential for the production of microalgae biomass and that the removal of contaminants (phycoremediation) was highly efficient during the period of microalgae cultivation.

These results may also subsidize the production of microalgae biomass on an industrial or semi-industrial scale in partnership with effluent treatment plants. The process of phycoremediation can be more efficient and less costly than conventional wastewater treatment (Lugo et al., 2020). Furthermore, the alternative use of agro-industrial residues to replace synthetic nutrients may further reduce the costs of microalgae biomass production and, consequently, expand its 
application. Many kinds of researches are being carried out to determine possible applications for the biomass of microalgae, many of them returning promising results, managing to add value to the generated compounds and/or insertion in existing processes (see review by Dias et al., 2019).

As an alternative source of nutrients, sugarcane vinasse was highly efficient in the enrichment of the algal culture. It is an acidic liquid, dark brown, and rich in organic compounds such as glycerol, lactic acid, sugars, nitrogen, and phosphorus (Ortegón, Arboleda, Candela, Tamoh \& Valdes-Abellan, 2016). Some authors have already evaluated the cultivation of microalgae in media enriched with vinasse; Chlorella vulgaris showed higher specific growth rates and lipid production when cultivated in anaerobically treated vinasse than when grown in a synthetic medium (Marques, Nascimento, Almeida \& Chinalia, 2013), and exhibited growth rates of up to 1.2 cells day $^{-1}$ when grown in $60 \%$ conventional filtered vinasse and $80 \%$ biodigested vinasse (Candido \& Lombardi, 2017). The enrichment of the medium with the chemical fertilizer NPK also provided the micronutrients needed for the development of $C$. sorokiniana. These nutrients were then supplied in a sufficient quantity to potentiate the development of microalgae.

The study of microalgal growth kinetics in an alternative culture medium is important for the use of formulations that allow faster and more efficient low-cost production strategies. The use of wastewater as a culture medium to support the production of microalgae improves the sustainability of the process and reduces the environmental burden generated when the effluent is improperly discharged into the soil or water resources. Nunes et al. (2021) presented results for the production of Chlorella vulgaris in wastewater from the dairy industry similar to those obtained in control culture (Bold Basal Medium). Andreotti et al. (2017) evaluated the potential use of Tetraselmis suecica, Isochrysis galbana, and Dunaliella tertiolecta in a multitrophic integrated aquaculture system, resulting in high $T$. suecica biomass yield (603 $\pm 34 \mathrm{mg}$ ) and the removal of more than $90 \%$ of dissolved inorganic nitrogen and inorganic diphosphorus.

Moreover, several studies have reported the highly efficient removal of inorganic nutrients, organic material, and heavy metals from effluent by microalgae, and some have reported improvements in effluent color following treatment with microalgae (Carvalho et al., 2012; Pires, Alvim-Ferraz, Martins, \& Simões, 2013; Satpal \& Khambete, 2016). This process, combined with the production of algal biomass and the decontamination of wastewater, reinforces the idea that microalgae have great potential for use in sustainable aquaculture.

Some metals present in the aquatic environment are of importance due to their high inherent toxicity, such as lead, cadmium, chromium, nickel, mercury, and, to a lesser extent, copper and zinc. Copper, zinc, and iron, among others, are micronutrients, and ideally should be present in trace concentrations in all aquatic environments. A trace element is a chemical element whose average concentration is very low (a "trace amount") and, therefore, does not cause any risk to human and animal health (Soto-Jiménez, 2011). The presence of these heavy metals at high concentrations and their toxicity to the environment and-humans is a major challenge when considering the treatment of wastewater effluent before its discharge into water bodies (Gautam, Sharma, Mahiya, \& Chattopadhyaya, 2014).

It was also observed a high rate of reduction of contaminants present in the culture medium in the 28 days of bioassay with microalgae. However, the adopted methodology limited us to certifying whether the microalgae promoted better the adsorption, biosorption, and/or transport of highly xenobiotic chemical elements in isolation. The ph monitoring and electrical conductivity of the water indicated that there is a constant biotransformation process during the 28 days of cultivation and intrinsic for each treatment. Encouraging the development of autochthonous microalgae in fish farm wastewater also played a key role in removing contaminants from wastewater. The elements that presented the greatest reductions in their concentrations, in decreasing order, were: Zinc, Lead, Aluminum, Manganese, Cadmium, Calcium, and Magnesium.

The reduction of high levels of pollutants in water can be observed in the literature that tested different sources of these pollutants through the use of different species of microalgae. Gani et al. (2017) reported the high efficiency of the 
algae Botryococcus sp. in the removal of $\mathrm{Cd}, \mathrm{Zn}, \mathrm{Fe}$, and $\mathrm{Mn}$ compared to a control group (wastewater without algae); in household wastewater, $\mathrm{Zn}, \mathrm{Fe}$, and $\mathrm{Mn}$ were removed by up to $71.5 \%, 51.2 \%, 83.5 \%$, and $97.2 \%$, respectively; and in food processing wastewater, the concentration of these metals was reduced by up to $64.4 \%, 53.3 \%, 52.9 \%$, and $26.7 \%$, respectively. Liu et al. (2018), Lugo et al. (2020), Shivagangaiah, Sanyal, Dasgupta and Banik (2021) also showed that microalga cultivation in wastewater has great potential to reduce contamination while generating economic benefits.

The production of Chlorella vulgaris in aquaculture wastewater was responsible for the reduction of high concentrations of phosphorus and total nitrogen (Blanco-Carvajal, González-Delgado, García-Martínez, Sánchez-Galvis \& Barajas-Solano, 2017). Barnharst, Rajendran and $\mathrm{Hu}$, (2018) developed a synthetic lichen-type biofilm using the fungus Mucor indicus and the microalgae C. vulgaris, and simulated the contamination of an aquacultural system. They found that the incorporation of this biofilm reduced the concentrations of several chemicals, including phosphorus and nitrogen, converting them into proteins and other cellular products and purifying the water. The system also rescued total ammonia levels in the water by $69 \%$.

Despite the promising results in the phycoremediation from wastewater, it is important to emphasize the methodological limitation in microalgal biomass flocculation. After chemical flocculation, there was a significant increase in iron concentration in the culture media, which required the addition of $0.75 \mathrm{~g}$ of ferric chloride $\left(\mathrm{FeCl}_{3}\right)$ per liter of medium. Thus, the use of chemical flocculation with ferric chloride to separate algal biomass should be performed with caution. During an evaluation of different flocculation techniques, Lal and Das (2016) determined that electro-flocculation was the most adequate and promising technique for the recovery of algal biomass in Chlorella sp. and Synechocystis due to its low cost and ease of use relative to chemical flocculation $\left(\mathrm{FeCl}_{3} ; \mathrm{KAl}\left(\mathrm{SO}_{4}\right)_{2}\right)$ and the use of chitosan. However, they did not investigate whether the chemical agents used during flocculation left residues in the water. In an investigation of non-chemical agents with the potential to be used in algal biomass separation, Abdul Hamid et al. (2014) concluded that using derivatives of Moringa oleifera as bio-coagulants provided several advantages, including a reduced impact on the environment, lower associated harvest costs, and is chemicalfree. Singh et al (2017), however, reported that centrifugation is more efficient and results in higher biomass yields in C. sorokiniana.

Based on the results we obtained, further studies are needed to identify flocculants that are less cumulative in the water. Studies are also required to better understand the synergistic and antagonistic processes involved in contaminant removal in residual fish farm wastewater by microalgae. However, the cultivation of microalgae using wastewater from artificial biosystems (aquaculture, fish farming, industrial and domestic effluent treatment) is a promising concept for the integration of biomass generation and chemical contaminant removal into wastewater.

\section{Conclusions}

Our results indicated that the production of microalgae biomass can be integrated with the treatment of fish farming effluents to reduce the environmental burden and increase the economic bonus for adopting a sustainable production method.

However, our results also indicated the importance of introducing a microalgae strain with high productive performance and supplementing the wastewater to obtain rapid biomass. The introduction of the Chlorella sorokiniana strain in fish farming wastewater and its enrichment with the chemical fertilizer NPK and sugarcane vinasse was essential for the high productive performance of microalgae biomass.

\section{Acknowledgments}

We appreciate the technical and financial support of Pro rectorate of Graduate Education and Research (PROPP) of the University of Grande Dourados (UFGD) for providing institutional and financial support and the PIBIC/CNPq scholarship 
granted to the first author; we also wish to thank the Foundation for Support to the Development of Teaching, Science and Technology of the state of Mato Grosso do Sul (Fundação de Apoio ao Desenvolvimento do Ensino, Ciência e Tecnologia FUNDECT) for financial support for Research Project 033/2015. We would also like to thank the National Council for Scientific and Technological Development (Conselho Nacional de Desenvolvimento Científico e Tecnológico - CNPq) for providing a scholarship the co-supervisor MSc. Nathaskia Silva Pereira Nunes, The Center for Research into Biodiversity; Dr. Jelly Makoto Nakagaki, the Laboratory of Applied Mass spectrometry and Chromatography; and Dr. Jorge Rapouso for allowing the use of laboratory room, and finally Mr. Anderson Greco for carrying out chemical analyses.

\section{References}

Abdul Hamid, S. H., Lananan, F., Din, W.N.S., Lam, S.S., Khatoon, H., Endut, A. E. \& Jusoh, A. (2014). Harvesting microalgae, Chlorella sp. By bioflocculation of Moringa oleifera seed derivatives from aquaculture wastewater phytoremediation. International Biodeterioration \& Biodegradation, 95,270 275. 10.1016/j.ibiod.2014.06.021

Andreotti, V., Chindris, A., Brundu, G., Vallainc, D., Francavilla, M. \& García, J. (2017). Bioremediation of aquaculture wastewater from Mugil cephalus (Linnaeus, 1758) with different microalgae species. Journal of Chemical Ecology, 33, 750-776. 10.1080/02757540.2017.1378351

Ansilago, M., Otonelli, F. \& Carvalho, E. M. (2016). Cultivo da microalga Pseudokirchneriella subcapitata em escala de bancada utilizando meio contaminado com metais pesados. Engenharia sanitária e ambiental, 21, 3, 10.1590/S1413-41522016124295

American Public Health Association- APHA (2005) Standard Methods for the Examination of Water and Wastewater. 21st Edition, American Public Health Association/American Water Works Association/Water Environment Federation, Washington DC.

Ballester-Moltó, M., Sanchez-Jerez, P., Cerezo-Valverde, J. \& Aguado-Giménez, F. (2017). Particulate waste outflow from fish-farming cages. How much is uneaten feed? Marine Pollution Bulletin, 119, 23-30. 10.1016/j.marpolbul.2017.03.004

Banerjee, G. \& Ray, A. K. (2017). The advancement of probiotics research and its application in fish farming industries. Research in Veterinary Science, 115, 66-77. 10.1016/j.rvsc.2017.01.016

Barnharst, T., Rajendran, A. \& Hu, B. (2018). Bioremediation of synthetic intensive aquaculture wastewater by a novel feed-grade composite biofilm. International Biodeterioration \& Biodegradation, 126, 131-142. 10.1016/j.ibiod.2017.10.007

Barros, A. I., Gonçalves, A. L., Simões, M. \& Pires, J. C. M. (2015). Harvesting techniques applied to microalgae: A review. Renewable \& Sustainable Energy Reviews - Journal, 41, 1489-1500. 10.1016/j.rser.2014.09.037

Blanco-Carvajal, E., González-Delgado, A. D., García-Martínez, J. B., Sánchez-Galvis, E. \& Barajas-Solano, A. F. (2017). Bioremediation of Aquaculture Wastewater Using Microalgae Chlorella vulgaris. Contemporary Engineering Sciences, 10 (45), 1701-1708. https://doi.org/10.12988/ces.2017.712198

Candido, C. \& Lombardi, A. T. (2017). Growth of Chlorella vulgaris in treated conventional and biodigested vinasses. Journal of Applied Phycology. 29, 4553. 10.1007/s10811-016-0940-2

Carvalho, E. M., Ottonelli, F., Ansilago, M., Godoy, H. C., Nakagaki, J. M. \& Ramires, I. (2012). Growth kinetics of the microalga Pseudokirchneriella subcapitata (Korshikov) Hindak (Chlorophyceae) in natural water enriched with NPK fertilizer. Biochemistry and Biotechnology Reports, 1, 14-18. $10.5433 / 2316-5200.2012 \mathrm{v} 1 \mathrm{n} 2 \mathrm{p} 14$

Dias, G., Hipólito, M., Santos, F., Lourega, R., Mattia, J., Eichler, P. \& Alves, J. (2019). Biorremediação de efluentes por meio da aplicação de microalgas uma revisão. Química. Nova, 42(8), 891-899. 10.21577/0100-4042.20170393

Food and Agriculture Organization- FAO (2018). El estado mundial de la pesca y la acuicultura 2018. Cumplir los objetivos de desarrollo sostenible. Roma. Licencia: CC BY-NC-SA 3.0 IGO.

Gani, P., Mohamed Sunar, N., Matias-Peralta, H., Abdul Latiff, A. A., Parjo, U. K. E. \& Oyekanmi, A, A. (2017). Green Approach in the Bio-removal of Heavy Metals from wastewaters. MATEC Web of Conferences, 103, 10.1051/matecconf/201710306007

Gautam, R. K., Sharma, S. K., Mahiya, S. E. \& Chattopadhyaya, M. C. (2014). Contamination of Heavy. Metals in Aquatic Media: Transport, Toxicity and Technologies for Remediation. In: Heavy Metals in Water: Presence, Removal and Safety. Edited by Sanjay K. Sharma. The Royal Society of Chemistry. 1-24 Published by the Royal Society of Chemistry. 10.1039/9781782620174-00001

Jung, J., Damusaru, J. Hyacinth, Park, Y., Kim, K., Seong, M., Je, H., \& Bai, S. C. (2017). Autotrophic biofloc technology system (ABFT) using Chlorella vulgaris and Scenedesmus obliquus positively affects performance of Nile tilapia (Oreochromis niloticus). Algal research. 27, 259-264. 10.1016/j.algal.2017.09.021

Kim, D. Y., Lee, K., Lee, J., Lee, Y. H., Han, J. I., Park, J. Y. \& Oh, Y. K. (2017). Acidified-flocculation process for harvesting of microalgae: Coagulant reutilization and metal-free-microalgae recovery. Bioresource Technology, 239, 190-196. 10.1016/j.biortech.2017.05.021

Lal, A. E., \& Das, D. (2016). Biomass production and identification of suitable harvesting technique for Chlorella sp. MJ 11/11 and Synechocystis PCC 6803.3. Biotechnology, 6, 41. 10.1007/s13205-015-0360-z 
Liu, Y., Lv, J., Feng, J., Liu, Q., Nan, F. \& Xie, S. (2018). Treatment of real aquaculture wastewater from a fishery utilizing phytoremediation with microalgae. Journal of Chemical Technology \& Biotechnology, 10.1002/jctb.5837.

Lizzul, A.M., Hellier, P., Purton, S., Baganz, F., Ladommatos, N. \& Campos, L. (2014). Combined remediation and lipid production using Chlorella sorokiniana grown on wastewater and exhaust gases. Bioresource Technology. 151, 12-18. 10.1016/j.biortech.2013.10.040

Lugo, L. A., Thorarinsdottir, R. I., Bjornsson, S., Palsson, O. P., Skulasson, H., Johannsson, S. \& Brynjolfsson, S. (2020). Remediation of aquaculture wastewater using the microalga Chlorella sorokiniana. Water, 12, 3144. 10.3390/w12113144

Marques, S. S. I., Nascimento, I. A., Almeida, P. F. \& Chinalia, F. A. (2013). Growth of Chlorella vulgaris on Sugar cane vinasse: The Effect of Anaerobic Digestion Pretreatment. Applied Biochemistry and Biotechnology, 171, 1933-1943. 10.1007/s12010-013-0481-y

Mcginn, P. J., Dickinson, K. E., Park, K. C., Whitney, C. G., Macquarrie, S. P., Black, F. J. \& O'leary, S. J. B. (2012). Assessment of the bioenergy and bioremediation potentials of the microalga Scenedesmus sp. AMDD cultivated in municipal wastewater effluent in batch and continuous mode. Algal Research, 1, 155-165. 10.1016/j.algal.2012.05.001

Mostafa, S. S. M. (2012). Microalgal Biotechnology: Prospects and Applications, Plant Science, Nabin Kumar Dhal and Sudam Charan Sahu, IntechOpen, $10.5772 / 53694$

Nunes, I. V. O., Inoue, C. H. B., Sousa, A. E. R., Carvalho, J. C. M., Gomes, A. M. A. \& Matsudo, M. C. (2021). Tertiary treatment of dairy industry wastewater with production of Chlorella vulgaris biomass: evaluation of effluent dilution. Brazilian Journal of Environmental Sciences, 56 (2), $365-373$. $10.5327 / \mathrm{z} 21769478787$

Ortegón, G. P., Arboleda, F. M., Candela, L., Tamoh, K. \& Valdes-Abellan, J. (2016). Vinasse application to sugar cane fields. Effect on the unsaturated zone and groundwater at Valle del Cauca (Colombia). Science of the Total Environment, 539, 410-419. 10.1016/j.scitotenv.2015.08.153

Pires, J. C. M., Alvim-Ferraz, M. C. M., Martins, F. G. \& Simões, M. (2013). Wastewater treatment to enhance the economic viability of microalgae culture. Environmental Science and Pollution Research. 20 (8), 5096-5105. 10.1007/s11356-013-1791-x

Sathasivam, R., Radhakrishnan, R., Hashem, A. \& AbdAllahd, E. F. (2019). Microalgae metabolites: A rich source for food and medicine. Journal of Biological Sciences, 26 (4), 709-722. 10.1016/j.sjbs.2017.11.003 (article in press).

Satpal \& Khambete, A. K. (2016). Waste Water Treatment Using Micro-Algae - A review Paper. International Engineering Management \& Applied Science Journal. 4, 2.

Shivagangaiah, P. C., Sanyal, D., Dasgupta, S. \& Banik, A. (2021). Phycoremediation and photosynthetic toxicity assessment of lead by two freshwater microalgae Scenedesmus acutus and Chlorella pyrenoidos. Physiologia Plantarum, 10.1111/ppl.13368

Singh, P. S., Singh, M. E. \& Taggar, M. S. 2017. Mass cultivation and harvesting of microalgae (Chlorella sorokiniana) for biomass and lipid production. International Journal of Chemical Science, Stud. 5 (5), 173-178.

Soto-Jiménez, M. F., (2011). Transferencia de elementos traza en tramas tróficas acúaticas. Hidrobiológica. 21, 239-248.

United States Environmental Protection Agency- USEPA (1986). Quality Criteria for Water. Office of Water Regulations and Standards Criteria Division, $\langle$ https://nepis.epa.gov/Exe/ZyPDF.cgi?Dockey=00001MGA.pdf〉.

Wuang, S. C., Khin, M. C., Chua, P. Q. D. \& Luo, Y. D. (2016). Use of Spirulina biomass produced from treatment of aquaculture wastewater as agricultural fertilizers. Algal Research. 15, 59-64. 10.1016/j.algal.2016.02.009 